\title{
Andaman Islanders and Polar Eskimos: emergent ethnographic subjects $c .1900$
}

\author{
Radcliffe-Brown Lecture in Social Anthropology \\ read 24 October 2012 by \\ KIRSTEN HASTRUP \\ Fellow of the Academy
}

Abstract: In this lecture the focus is on A.R. Radcliffe-Brown's ethnographic work, notably his fieldwork in the Andaman Islands in 1906-8. About the same time, the Danish ethnographer Knud Rasmussen studied the Polar Eskimos in North-West Greenland. While sharing a general quest for ethnographic description of little-known groups, they styled their fieldwork in different ways, saw colonialism in different terms, adhered to different knowledge traditions, and not least, worked in different natural environments. This resulted in very distinct portraits of 'the natives', which were to cast long shadows into the present, within which the history of first encounters is firmly embedded.

Keywords: ethnographic fieldwork, spatial history, colonial encounters, narrative styles.

\section{INTRODUCTION}

Anthropology took off from an enlightenment tradition of empirical studies of the world, and aimed at systematic classification and general understanding of its workings. While many proto-ethnographic observations and descriptions made by naturalists, merchants or missionaries circulated well before 1900, it was not until then that systematic long-term ethnographic observation, took off. As stated by Tim Ingold in his Radcliffe-Brown lecture in 2007, anthropology and ethnography are not the same thing, even if closely connected in our practice; while anthropology pursues 'the great questions of social life', 'ethnographers describe, principally in writing, how the people of some place and some time perceive the world and how they act in it' (Ingold 2008: 90). 
On this definition, my two main characters certainly qualify as ethnographers, both making their first contributions shortly after 1900, through their engagements with particular fields that were as wide apart as were their inspirations and ambitions. The first one, of course, is Alfred Reginald Radcliffe-Brown (1881-1955) to whose memory this series of lectures is dedicated, and whose first fieldwork took place in the Andaman Islands in 1906-8 (Radcliffe-Brown 1922). He is a very well known figure in British and international anthropology, and often seen as the key figure in modernising the discipline (Kuper 1977a; Ingold 2008). The second is Knud Rasmussen (18791933), a largely self-taught Danish ethnographer of the Eskimo peoples of Greenland and Arctic North America, who were to prove the intimate linguistic and cultural connection between all Eskimo groups from Greenland, through Canada and Alaska, and onto the eastern tip of Siberia. Among other things, this was to earn him an honorary doctorate at St Andrews University in 1927, at the time when the Norwegian explorer and statesman Fridtjof Nansen was Lord Rector. However, his first substantial ethnographic work was the book about the Polar Eskimos, a tiny group of people (counting 250 souls) in the far North Western corner of Greenland, among whom he sojourned in 1903-4 (Rasmussen 1905; 1906; 1908). This region was later to become known as the Thule District, invoking ancient images of a place where partly mythical northern barbarians lived (Hastrup 2007).

Located in the Indian Ocean and the High Arctic, respectively, the two men's fields were not only wide apart, they were also known to different degrees and through rather different historical trajectories. I shall argue that the historical difference deeply infiltrated later ethnographic perception of the localities studied. Beyond the individual peculiarities and regional differences, my hope is to show how distinct ethnographic subjects emerged in the course of ethnographic writing, and how the ethnographic moments, as proposed by Marilyn Strathern (1999), are replete with previous encounters and perceptions. Even today, I argue, we seem to be caught up with the particular ethnographic subjects that grew out of the first (professional) ethnographic descriptions.

In pre-anthropology times there were few terms by which to classify people. Mankind was by canonical standards something in itself, defying incorporation into natural systems. In the 18th century, much to the consternation of the Pope, Linnaeus included people in his classification of animals, and invented the term homo sapiens (Pratt 1992: 32). By 1758, homo sapiens had been divided into six classes summarised by Mary Louise Pratt in the following way: 
Wild Man. Four-footed, mute, hairy.

American. Copper-colored, choleric, erect. Hair black, straight, thick; nostrils wide; face harsh; beard scanty; obstinate, content, free. Paints himself with fine red lines. Regulated by customs.

European. Fair, sanguine, brawny. Hair yellow, brown, flowing; eyes blue; gentle, acute, inventive. Covered with close vestments. Governed by laws.

Asiatic. Sooty, melancholy, rigid. Hair black; eyes dark; severe, haughty, covetous. Covered with loose garments. Governed by opinions.

African. Black, phlegmatic, relaxed. Hair black, frizzled, skin silky; nose flat, lips tumid; crafty, indolent, negligent. Anoints himself with grease. Governed by caprice.

Monster. Including dwarfs, giants and eunuchs. (Pratt 1992: 32)

As Pratt observes, such categorisation of humans is explicitly comparative. What is more, clearly social values and political facts creep in upon the physical appearance -naturalising the idea of European supremacy in the process. A hundred years later, Lyell and Darwin put forward a theory of unity of the human race, which was still disputed on ethnographic grounds, however, as we can read in an article published in the Transactions of the Ethnographical Society of London (Crawfurd 1865: 60).

The two different peoples portrayed by Radcliffe-Brown and Rasmussen were also only known in rather general, racial terms before the two men entered upon the scene. These pre-established images of course affected their writing, which again influenced future ethnographies, as I have experienced very forcefully myself, during recent work in North West Greenland, the very place where Rasmussen's ethnographic career began (Hastrup 2007; 2009). This raises the question of the nature of anthropological knowledge more generally, and not least how it may contribute to answering 'the great questions of social life' (Ingold 2008: 90). The challenge is one of getting beyond simple allegations of regionalism (cf. Fardon 1990), while still being perceptive to real difference. I shall argue that the persistence of particular images has a lot to do with narrative styles, which again are favoured by particular landscapes and social forms. Elsewhere, I have suggested that in the field we move about in particular emotional topographies, loaded with past and present stories and events, as well as the features of the landscape (Hastrup 2010a).

My argument moves towards such larger questions through, first, a discussion of spatial histories as formative of distinct topographies of knowledge, featuring their own values and sensations, and second, by presenting the different methodological strategies of the two ethnographers, displaying remarkable differences in their personal engagements with people. Third, and last, I shall discuss how the narratives of the two men cemented particular views and historical realities in their featuring distinct historical 
topographies. My references to their rich work are of necessity highly selective, but I hope readers will sense how, by looking closely into the makings of ethnography, one actually gets close to large questions about anthropological knowledge.

\section{SPATIAL HISTORIES: KNOWING PEOPLE WHERE THEY ARE}

History is always in some sense spatial; it is both configured by and configures particular topographies of being and knowing. In Lucien Lefebvre's view, space is where a historical plot unfolds, while simultaneously constituted as a place by the history itself (Lefebvre 1991). This idea of a spatial history resonates with David Turnbull's notion of a 'knowledge space' as an 'interactive, contingent assemblage of space and knowledge, sustained and created by social labour' (Turnbull 2003: 4), stressing the fact that all knowledge is entrenched both in particular places and in social communities. Once established, knowledge spaces take on a kind of naturalness that tends to hide both of these features. 'Societies' and 'cultures' are equal examples of this, as are disciplines, as we have come to know them. However, these domains are best seen as located fields of practices rather than networks of concepts and statements (cf. Rouse in Turnbull 2003: 10). This certainly sits well with the practice of ethnographic fieldwork in particular conjunctures of history and space.

In both of my cases, it is clear that colonial map-making (in brief) resulted in placing and perceiving the Andaman Islands and the Thule District as frontier zones, whose inaccessibility and remoteness, when seen from the different colonial centres, were forever to be inscribed on the people living there (Vaidik 2010; Hastrup 2013c). Modern ethnographic work in both places inevitably is linked to earlier descriptions and histories (see e.g. Pandya 2007; 2009; and Hastrup 2013a). While there are very few likenesses between the Andamans in the Indian Ocean and Thule in the High Arctic, they share a feature of having been rumoured to be wild places, inhabited by equally wild people, before they became subject to ethnography. The insularity of the places was inscribed upon their inhabitants, well before the ethnographers entered the scene, as was their position in the larger scheme of peoples and its basic distinctions. Black and white, Negrito and Eskimo, were seen as natural facts. Thus, in an article on 'Wild men and beast-children' from 1863, E.B. Tylor wrote matter-of-factly: 'The native Australian and the Andaman Islanders may be taken as fairly representing the lowest state of human society of which we have any certain knowledge' (Tylor 1863: 21).

In a similar fashion, the first person to report on Polar Eskimos (before they were known by the name), labels them within a general scheme. I am referring to Captain John Ross, reporting on his voyage to the North on behalf of the British admiralty to explore a possible NW Passage in 1818. Ross did not find such a passage, but he met 
some of the unknown people that dwelled in North West Greenland, far north of the Danish colonies and outside any colonial interest - while also virtually inaccessible due to the ice-packed sea. His was actually the earliest written report of an encounter with these people, whom he affectionately referred to as Arctic Highlanders-establishing his own analogy of the familiar. Ross wrote:

The origin of the Arctic Highlanders, or inhabitants of Prince Regent's Bay, is a question as yet involved in peculiar obscurity. They exist in a corner of the world by far the most secluded which has yet been discovered, and have no knowledge of anything but what originates, or is found, in their own country; nor have they any tradition of how they came to this spot, or from whence they came; having, until the moment of our arrival, believed themselves to be the only inhabitants of the universe, and that all the rest was a mass of ice. (Ross 1819: 123-4)

It is his own astonishment as well as theirs that he gives away here: How had they happened upon this godforsaken, deep-frozen land; and how could they still be so strikingly merry? When the far northern peoples again came into view with Peary's expeditions in the 1890s they were portrayed as excellent and ingenious companions, as honest, hard-working and artistically gifted — even if outwardly rather 'uncivilised'. In his brief description of the Smith-Sound Eskimos, Robert Peary stated that, 'I have merely endeavoured to sketch an outline picture which shall show this most interesting people in their true light, and do justice to the fearless, hardy, cheerful little tribe for whom I have the warmest regard' (Peary 1898: 479, n. 1). He went on to suggest that there was an untouched mine awaiting work in this Arctic Oasis, and over and again he stressed the kindness and ingenuity of the people. Yet in his introduction, even he attempts to stand back and position the group within a larger scheme:

Scattered along the shores of the Arctic oasis already described, this little tribe, or perhaps more properly speaking, family of Eskimos-for they number but two hundred and fifty-three in all, men, women, and children - is found maintaining its existence in complete isolation and independence, under the utmost stress of savage environment. Without government; without religion; without money or any standard of value; without written language; without property, except clothing and weapons; their food nothing but meat, blood, and blubber; without salt, or any substance of vegetable origin; their clothing the skins of birds and animals; almost their only two objects in life, something to eat and something with which to clothe themselves, and their sole occupation the struggle for these objects; with habits and conditions of life hardly above the animal, these people seem at first to be very near the bottom scale of civilisation; yet closer acquaintance shows them to be quick, intelligent, ingenious, and thoroughly human. (Peary 1898: 479-81)

Peary spent many years there on and off in the period 1891-1909, while he mapped northern Greenland, mostly in the interest of finding the best possible place to head 
out for the North Pole (and succeeding in 1909), and he depended totally upon their skills for his survival (first) and (later) his success. He stresses that this simple, cheerful, and hospitable people surpasses any other known people in endurance, and in their ingenuity and the intelligence displayed in making use, to the fullest extent, of every one of the few possibilities of their country which can assist them to live and be comfortable, they are, in my opinion, ahead of any other aboriginal race. Of arts, sciences, culture, manufactures, and such other adjuncts of civilization, they know nothing' (Peary 1898: 492).

If insularity and lack of civilisation were thus constant features in descriptions of the Arctic Highlanders (or Smith Sound Eskimos), they were also attributed to the Andaman Islanders. The latter had come into view at a much earlier time, however, and their fate had been to be originally perceived as hostile and barely human, where the Eskimos were mostly seen as friendly, humorous, intelligent, and totally dependable by disposition. Thus, when Radcliffe-Brown met the Andaman Islanders, they were already well-known savages of the Indian Ocean, who had only recently been (partly) tamed by the British.

Descriptions go back to early Arabian travellers and to Marco Polo. RadcliffeBrown quotes Marco Polo in his introduction, setting the scene: 'Angaman is a very large island, not governed by a king. The inhabitants are idolaters, and are a most brutish and savage race, having heads, eyes and teeth resembling those of the canine species. Their dispositions are cruel, and every person, not being their own nation, whom they can lay their hands upon, they kill and eat' (Marco Polo, in RadcliffeBrown 1922: 7; see also Vaidik 2010: 18). Marco Polo never visited the islands, but rumours had the islands feared and best avoided. In the fourteenth century, John Mandeville continued the misanthropic depiction of cannibals, and added that in one of these islands 'there is a race of great stature, like giants, foul and horrible to look at; they have one eye only, in the middle of their foreheads. They eat raw flesh and raw fish' (quoted by Vaidik 2010: 18). Here they fall out of humanity proper and into the category of monsters.

Among the persistent images throughout the centuries is the view of the Andaman Islanders as cannibals. Edward Horace Man, whose description of the Andaman Islanders from 1885 is the baseline of Radcliffe-Brown's work, suggests that 'the origin of the belief . . . may possibly be traceable to the inveterate hostility which they have manifested towards all strangers approaching their shores, but for which abundant excuse can be found in the accounts given by Capt. Miller of the malpractices of the Malay and Chinese traders who visited these islands in search of bêche de mer and edible birds' nests' (Man 1932: xviii). The reference to Captain Miller indicates the re-entrance of the British upon the scene, and this was the beginning of a gradual redemption of the islanders' humanity and morals. 
The first British encounters had been less embracing. In 1789 the islands were annexed by the British in a general move to conquer the sea and the trade routes towards the east, and also to establish a penal colony. This was done after a survey made by Lieutenants Colebrooke and Blair; Colebrooke claimed that the islanders were 'a race of men the least civilized, perhaps, in the world; being nearer to a state of nature than any people we read of' (in Anderson 2011: 70). Direct encounters were few, however, and when they occurred they seem to have been marked by hostility, and apparently only by downright kidnapping did it seem possible to study them more closely, and to measure these humans. The details are many, but lack of space prevents me from delving into them. I shall just note that in the first British move towards the islands, $c .700$ Indian convicts were transported there between 1793 and 1795. Already in 1796 the colony was abandoned, however, due to sickness and immense death tolls on the infested islands. Here the killer was tropical humidity and insects, while it had been pack ice and cold in the early 19th century expeditions to the Baffin Bay, in search of the North West Passage.

The second British attempt at colonising the islands was more successful, although not based on any particular kindness towards the inhabitants. In 1856, the commissioner of Burma, Henry Hopkinson, wrote about the magnificent position of the islands, its many fine harbours, and the unmistakable fertility of the soil, and found it 'astonishing' that,

instead of offering a refuge to the miserable storm-driven vessel, they should be a snare in her path leading to utter destruction, and in place of engaging the enterprise, and furnishing subsistence to thousands of colonists, they should be left in the possession of a handful of degenerate Negroes, degraded in habits and intelligence to a level little above the beasts of the forest with which they dwell. (Hopkinson 1856; in Anderson 2011: 71)

Colonisation was resumed soon after, when the mutiny in India made the need for new penal institutions urgent, but also clearly with a view to other colonial interests (see Anderson 2007). Soon after, a new wish to establish friendly relations with the natives was voiced by more enlightened officers, as we saw above. Thus, the modern, colonial history of the Andaman Islands effectively dates back to 1857, as noted by E.H. Man (1932: xix). It was E.H. Man's father who in January 1885 took possession of the Andaman Islands in the name of Queen Victoria, and took charge of the penal colony. It was also he who urged his son to make a proper description of the people, which was first published in (successive issues of) Man. Journal of the Anthropological Institute in 1885 (and later reprinted as a monograph published by the now Royal Institute in 1932). E.H. Man was quite taken by the scenery of the islands: 
The natural beauty of the scenery of the Andamans never fails to awaken the admiration of every visitor, and has been deservedly eulogised by various writers, one of whom (Prof. Ball) says: 'Of all the places I have seen in Europe, Killarney can alone convey an idea of these scenes. The Blue waters, the luxuriant emerald green vegetation down to the margin of the coast, and the passing showers which brighten all the aspects of nature, have their counterpart there.' (Man 1932: xvi)

This is clearly the vision from the ocean, clad in an analogy from home. From within, the landscape was far more forbidding, as the early colonisers had experienced. In fact, the two different landscapes made Radcliffe-Brown distinguish between coast-dwellers and forest dwellers, the latter being less nomadic in their habits than the former (1922: 30). 'One of the reasons for this is that as they cannot convey their belongings from one place to another by canoe, but must carry them overland, the moving of a camp is a more tiresome business with them than it is with the coastdwellers' (ibid.). This is not so surprising in itself, but what is lacking in his discussion is whether they are actually two distinct groups, or whether everybody moves about. In his introduction to the monograph, Radcliffe-Brown lists the names of various groups, or tribes, and refers to a map from 1858, and to a note made by Colebrooke in 1790 (1922: 13-15), but it is unclear whether they are still relevant. The question is raised indirectly, when Radcliffe-Brown admits that it 'is not possible to give accurately the area occupied by each tribe, as the boundaries are difficult to discover' (1922: 15). He notes that in 1858 , the estimated population of all the islands was about 5,500 (ibid.: 18-19).

In 1901, a census was made, enumerating some 625 natives of the Great Andaman and 1,257 on the four other islands, and in discussing these numbers we hear about the movements he himself made on the islands, and we implicitly understand that Radcliffe-Brown hardly ventured inland on Great Andaman, but mostly talked to people in the Port Blair region. He claims that he saw a total of 500 natives at different times (1922: 18), and in small slippages of language, referring to the 'friendly Andamanese' he worked with in the more heavily colonised part of the Andaman Islands, we understand that his subjects were mostly people coming and going in the colony, and to some extent mixing with the prisoners. In actual fact, he seems to rely rather heavily on earlier works, such as the one made by E.H. Man, to which I referred above (see also Kuper 1975: 58).

At the time, the Andamanese hostility or resistance to the British had gradually broken down; it became increasingly difficult to escape to the inland areas that were gradually turned into forestry reserves and cultivated in other ways, and the original inhabitants were incorporated into the labour regime as were the prisoners. In the process, their numbers were decimated to the point of extinction, not least due to syphilis, a new killer disease. It was at that moment that proper recording began, and 
when the fierce natives were narratively tamed. The historian Aparna Vaidik writes (in 2010):

With time, several conscientious officials who witnessed the destruction of the tribes took it upon themselves to document the lives and mores of the Andamanese. E.H. Man, M.V. Portman and R.C. Temple were the earliest to get down to this task. By the early twentieth century, ethnographers and anthropologists such as A.R. RadcliffeBrown also made their way into the Settlement. The anthropological enterprise became the handmaiden of empire. Thereafter the presence of the Andamanese in the space that the British created came to be defined by their quarantined existence within the confines of academia. (Vaidik 2010: 130)

The allegation of anthropology being the handmaiden of empire is not new, but it is somewhat surprising that academic anthropology is seen to confine the islanders even further than colonial history itself. Truly, anthropology added new weight to the spatial history, but one could argue that it was so much part of it that it is difficult to uphold a distinction. Both colonial administrators and anthropologists were parties to a spatial history that affected them all. Radcliffe-Brown certainly saw no conflict of interest with colonialism, and explicitly saw anthropology 'as a study which has an immediate practical value in connection with administration and education of backward peoples' (1929, in Radcliffe-Brown 1958: 39). Such practical value was entrenched in his view of anthropology as a comparative sociology, aiming at discovering general laws; this was seen in opposition to Boas's historical method, which Radcliffe-Brown saw as 'ethnology', best kept apart from social anthropology (Radcliffe-Brown 1951; in Kuper 1977a: 53-4).

Boas provides the cue for letting our second protagonist enter the scene in the Arctic, where he was destined to study the Eskimos, pioneered by Boas himself (1888). In one of his writings, Knud Rasmussen poetically says: 'From the bottom of my heart I bless the fate that had me born at a time where polar research by means of dog sledges had not yet become outdated'(1932: ii). His chosen mode of transport was not only a means to get from one place to another in the ice and snow-covered landscape, but also to inscribe himself into the High Arctic topography, in a way similar to that of the Eskimos themselves. From this position it was impossible to keep an external perspective upon the people. For better or worse, Knud Rasmussen was as much part of the environment as the Eskimos were, and by travelling like them and with them, he came to share their sense of place (Hastrup 2006). This meant that his ethnographic work was to contribute to, and elaborate on, the spatial history of the locals rather than the colonisers.

In 1905, Knud Rasmussen published his first book, Nye Mennesker in Danish ('New People'), based on his two years' expedition (1902-4) to the northernmost settlements in Greenland, the land of the Arctic Highlanders or the Smith Sound 
Eskimos (Rasmussen 1905). The book appeared in an English translation together with another early work, Under Nordenvindens Svøbe ('Under the Lash of the North Wind'), from 1906, in which material from other parts of Greenland was also presented (Rasmussen 1908). In the preface, he writes how the inspiration for the expedition derived from a tale, told to him by an old Greenlandic woman, about how 'far away North, at the end of the world, there lived a people who dressed in bearskins and ate raw flesh. Their country was always shut in by ice, and the daylight never reached over the tops of their high fjelds. Whoever wished to go there, must travel with the South wind, right up to the Lord of the wild northern gales' (Rasmussen 1908: xix). If Knud Rasmussen was driven by a wish to discover an unknown people, by referring to the old woman's tale — as told to himself — he had already incorporated it into his own story. It was he who named these bearskin-clad people 'Polar Eskimos', and in that sense, he discovered and defined them in one move. Yet, the tiny Eskimo population in the region was not totally unknown to westerners when Rasmussen arrived in 1903, as I have hinted at above.

Apart from the reports made by Captain Ross in 1818 and Robert Peary in the 1890s, Eivind Astrup - who took part in Peary's earliest expeditions - had also written a whole book about the Polar Eskimos, giving a vivid and generous portrait on their intelligence and skills. His book was published first in Norwegian (which was almost the same as Danish at the time), under the title 'Among the Neighbours of the North Pole' (1895); when it was later translated into English, its title had-significantly-become With Peary near the Pole (Astrup 1898). The titles were catering for different markets, which by the end of the nineteenth century had become increasingly influenced by the sensationalist press in America (and Britain), while not yet so in Scandinavia (Riffenburgh 1993). The development of the press entailed that heroism increasingly adhered to Arctic expeditions. No doubt this was also an implicit feature in the general emphasis on 'first encounters'. Having finally ventured upon human dwellings, Astrup thus told about the first meeting on 23 July 1891:

Of the eleven inhabitants of the place, the men immediately came down to the beach to meet us, whilst the women and children cautiously kept in the rear. A couple of us involuntarily extended our hands towards them in friendly greeting; but to our surprise, instead of grasping them they stood staring at us, without the slightest idea of what such an advance should signify. Soon, however, they saw that we intended well, and then they gave us a warm welcome. (Astrup 1898: 73-4)

Astrup adds that 'it was evident that they had never been in touch with the civilised world, or seen a vessel, which was to their eyes most remarkable' (1898: 74). There are significant echoes of John Ross here, becoming more conspicuous in the ensuing descriptions of the filthiness and general appearance of the Eskimos. The thickness of 
Astrup's ethnographic description far exceeds Ross's, however. In conclusion of a lengthy discussion of their sociality, and their natural good disposition, Astrup says: 'It may be safely said that liberty is the guiding principle among these happy citizens; not that liberty which is bounded by the strict letter of the law, but liberty as complete as one could hope for in this world, the liberty of mutual confidence' (Astrup 1898: 290).

When Knud Rasmussen published his book about the New People, he certainly under-communicated the fact that others had been there before him, even if it is evident that earlier accounts weave themselves into his imagery and stories (and he does mention Astrup in passing). While explicitly framing his narrative by the old woman's tale and his own dream, in actual fact he was as much guided by earlier accounts. $\mathrm{He}$ knew of the new people, before he met them. When, finally, after an extremely demanding journey on their sledges across the dreaded Melville Bay, which had cut off these people for centuries, he and his Greenlandic companion, Jørgen Brønlund, spotted a black dot in the distance, and it gradually grew into a sledge, he relates:

We were half mad with delight, and could only call out each other's names. Speed signal! The dogs drop their tails and prick up their ears. We murmur the signal again between our teeth, and the snow swirls up beneath their hind legs. A biting wind cuts us in the face. At last! at last! people, other people, the new people-the Polar Eskimos! (Rasmussen 1908: 6)

Incidentally, they were not yet Polar Eskimos when Rasmussen met them; this was a name that he bestowed upon them in his book. The Eskimo couple first seen on the sledge were clad in bearskin and fox and met them with curiosity and astonishment. They were perfectly able to understand each other's language (Knud Rasmussen being fluent in West-Greenlandic from his upbringing until the age of 12 in his father's vicarage further south), and when introductions had been made, the man turned to his wife and exclaimed: 'White men! white men! . . White men have come on a visit' (Rasmussen 1908: 7). If Knud Rasmussen did not know what to expect, the Eskimos did. The 'first' encounter was understood through received categories of mimesis and alterity on both sides (Taussig 1993).

Let us read Knud Rasmussen's first impressions on approaching the dwellings at Agpat where his first new friends took him; when they arrived within calling distance, the man from the sledge screamed out a deafening 'White men! white men!'

The people, who had been moving briskly about among the houses, stood still, and the children left off their play.

'White men! white men!' repeated the young fellows who had joined us. Our dogs drooped their tails and pricked up their ears as a many-tongued roar from the land reached us. And then, like a mountain slide, the whole swarm rushed down to the 
shore, where we had pulled up-a few old grey-haired men and stiff-jointed old crones, young men and women, children who could hardly toddle, all dressed alike in these fox and bear-skin furs, which create such an extraordinarily barbaric first impression. Some came with long knives in their hands, with bloodstained arms and upturned sleeves, having been in the midst of flaying operations when we arrived, and all this produced a very savage effect; at the moment it was difficult to believe that these 'savages,' 'the neighbours of the North Pole,' as Astrup called them, were ever likely to become one's good, warm friends. (Rasmusssen 1908: 9-10)

They did become friends, however, and I would venture that it happened instantaneously; from his unpublished diaries, there is no doubt that he saw them eye-to-eye the minute he met them, and he mused about how to present them, and not least the problem of finding a title for the book that could convey how 'the Polar Eskimos are a free people, living in an un-possessed, free country, outside of any law'. (Diary from Den danske litercere ekspedition til Grønland, 1902-4, book 7, unpaginated; The Royal Library, Copenhagen). Rasmussen felt compelled to underscore their unknownness and potential wildness to attract readers who otherwise, and for the first time, would be able to read about Eskimos as individual and impressive humans - and New People was the choice made. More generally, I want to note that he began 'writing' long before he sat down to it.

It may be that lawlessness was seen as a more general feature of primitive society at the time, but what is striking about Knud Rasmussen's work is his deep respect for Eskimo social life outside the law, for which Astrup's book might have prepared him. They lived in blissful freedom, he seemed to think, while also knowing the limitations put upon it by nature itself. An example is provided by his description of the old bear hunter Sorqaq, who declared one morning that a man who idled about the house when spring had arrived was wasting his life. Consequently, he called his dogs and harnessed them to his sledge, and prepared to take off travelling and hunting.

'It has come to pass that a man starts on his travels!' he called abruptly in at a window: that is the Polar Eskimo's farewell. 'Great Sorqaq is going!' echoed from within, and the people rushed to accompany him as far as the ice.

'Without a wife —old man's fashion!' one called jestingly after him.

'Quite right! Old men are always satisfied with the women they happen upon. And where men are gathered together, there is pretty well always a woman as well,' retorted old Sorqaq, with a laugh. Then he swung his whip high over his head. The dogs sprang yapping across the ice and tore off in a playful gallopade. Soon the sledge was out of sight.

Happy Sorqaq! Thou wast born with an energy that will never let thee rest. Thou must live travelling because thou canst not stand always and every day to return to the pen. The domestic animal nature has never formed part of thy disposition. 
The world is large that men may take it in possession. And so, when the traveling fever comes over thee, then do thou fling thyself on thy sledge, lord of the day, master of thy dogs! (Rasmussen 1908: 42-3)

The reported freedom and bliss should be seen against the stark poverty in which the Polar Eskimos found themselves in early 20th century; Marcel Mauss reports (on the basis of collected evidence from all available sources) that this particular group of Eskimos was exposed to more hazards than anyone, and that their material culture had declined considerably, due to a long period of packed ice, which had walled them in and prevented any driftwood from reaching them (Mauss 1979). This destitution had been somewhat relieved by Peary, who had brought rifles and ammunition that allowed them to hunt more efficiently, and it was the main inspiration for Knud Rasmussen to establish a permanent Danish presence in the region (Rasmussen 1921).

The great paradox in the life of this freedom-loving, moving ethnographer is actually that he was the one to finally 'colonise' the Polar Eskimos - who until then had lived in an unclaimed region of Greenland. He tried to persuade the Danish state to extend their colonies to the far North, but that was of no interest, access being far too complicated and the gains non-existent. So he took it upon himself to establish a colony, in terms of a mission and a trading post in 1910. This was the Thule Station, by which the primary ethnographic 'conquest', if you wish, was definitively lifted out of the mode of exploration and expedition, and into the mode of colonisation and a more professional ethnographic interest. It was also the moment, when Ultima Thule finally found a fixed place on the map.

The historical moment itself fuelled two contradictory trends in Knud Rasmussen's own writings, one of nostalgia for aboriginal man, another of modernist mission. The latter was epitomised in the Thule Station, allegedly designed to help the Polar Eskimos make the transition from an isolated hunting community to a modern society. The means were Christianity, trade, modern technical equipment, health care and local laws (Rasmussen 1921). The Thule Station and the profits from the fur trade were meant to fulfil this ambition. The profits also financed most of Rasmussen's seven Thule expeditions, of which the Fifth Thule Expedition (1921-4) — charting the links between the various Eskimo groups from Greenland across Canada to Alaska-is the best known to anthropologists (Rasmussen 1925-6). As observed by Johannes Fabian for central African explorations, once stations-however scientific and friendly - were established, the political relations between hosts and guests changed; at the station 'exploration reached the end of the road and turned into colonization' (Fabian 2000: 48).

Looking back upon the two ethnographers' appropriation of their fields, RadcliffeBrown arrived in a colonised place with a long and complex history of hostility and bad press, to which he added his own observations to those of Portman and Man 
(whom he acknowledges), both colonial officers. Knud Rasmussen arrived in a little known territory and fell in love with the people - as had Astrup before him. Eventually, he was to colonise them, but 'in their own interest' - to make sure that they remained free. His encounter was further coloured by the fact that Arctic exploration was imbued with heroism, due to the frozen and inaccessible landscape having led to numerous shipwrecks and other disasters. This again had bestowed the Arctic with a deep and persistent sense of the sublime - in the sense suggested by Edmund Burke in 1757, incorporating a sense of terror along with beauty (Hastrup 2013a).

In the above, I hope to have suggested how space, knowledge, and history merge in the perception of particular places and their peoples. To Lefebvre's spatial history we may thus add a dimension of Doreen Massey's notion of elusive places, which points to 'place' as an event of configuration. It is 'the coming together of the previously unrelated, a constellation of processes rather than a thing. This is place as open and multiple. Not capturable as a slice through time in the sense of an essential section. Not intrinsically coherent' (Massey 2005: 141). The Andaman Islands and the High North were equally susceptible to such configuration and, as I have shown, even the 'quarantined existence' within academia is circumscribed by intricate social and historical processes of mapping, knowing, and narrating that originate from without, yet deeply infiltrate later ethnographic description.

\section{ENGAGEMENT: METHODOLOGICAL STRATEGIES}

Like Fridtjof Nansen, who had launched the 'sportsman's method' in Polar exploration, which not only referred to his skiing but also to the careful selection of a small but well trained group of participants (Huntford 1997: 131), Rasmussen operated on a small scale and with native means of transport. The dog sledge enabled him to perceive the Arctic landscape from the perspective of the people dwelling there (cf. Ingold 2000). In other words, the topographic inscription allowed for a presentation of the Eskimos from within their own horizon. This was very different from RadcliffeBrown's approach.

The horizon was not only set by the elements of nature, but also by their storytelling, a favourite pastime in the long winter night. Rasmussen's main objective was to collect and write down as many tales, myths, and songs as possible. He worked in the European folkloristic tradition, imported into America by Franz Boas, the geographer turned ethnographer in the German tradition of cultural history. Boas propounded a historical method built upon a unified view of mankind. In a letterdiary from his expedition to Baffin Island 1883-4, he writes: 'I believe that if this trip 
has a significant impact on me as a thinking person, then it is the strengthening of my notion of the relativity of all education and the conviction of how the value of people lies in the guidance close to their heart [Herzensbildung], which I find, or miss here, just as at home' (23 December 1883; in Müller-Wille 1998: 159). He met people directly and as individuals with distinct dispositions, and he was proud of living like them and acquiring some of their skills; in fact, he had little choice, since where he worked there was nowhere to meet the people outside their own world. He depended upon their individual skills of survival in the Arctic winter, and there was no way he could simply treat them as a (racial) category. This is still the case.

Boas eventually became a great collector of myths and stories, believing firmly that they would give access to the core of a people's visions of the world. This view of a narrative entry into culture was the foundation for Knud Rasmussen's fifth Thule Expedition 1921-4-covering all Eskimo Groups across the North American continent and beyond. His own task was to describe the 'intellectual culture' of the Eskimos, while a trained ethnographer from the National Museum in Copenhagen should study and collect the 'material culture'. Rasmussen was struck by the Eskimo skill at storytelling, and asserted that their knowledge was based in experience rather than theories, and suggested:

This it is which always gives their accounts that delightful originality which is the peculiar property of those whose theories are based on experience of life itself. Their naturalness makes of them philosophers and poets unawares, and their simple and primitive orthodoxy gives to their presentment of a subject the childlike charm, which makes even the mystic element seem credible. (Rasmussen 1929: 33)

Rasmussen knew that to distinguish the material from the intellectual culture was not easy in practice. He noted that it was natural for an explorer to start with a description of the geography and the material culture by which people make a living, before proceeding to the intellectual life (Rasmussen 1929: 10). Nevertheless, it was the stories which drew him. He was a great conversationalist anyway, always engaging with people, and his main interest was to document and preserve stories within which untold historical processes were hidden.

Rasmussen made some interesting observations on method in relation to this collection of elements of intellectual culture. Collecting their tales, narratives, and biographies as well as understanding their beliefs made Rasmussen realise that 'I had to place myself in their position' (1929: 20). In an interesting echo of Malinowski's (still unknown or at least unacknowledged) 1922 statement about the native point of view, Knud Rasmussen says: 'it has always been one of my main objects, in the portrayal of primitive culture, to get the natives' own views of life and its problems, their own ideas expressed in their own fashion. This was often quite as important to me as 
eliciting new elements in their religious and spiritual life' (ibid.). Already in his first book, he wrote about his practice of 'collecting' tales:

These fables and legends were written down during the Polar Night. They are told in the houses at this Season, when the Eskimos, after great banquets of raw, frozen meat late in the evening, are digesting their food and are heavy and tired. Then it is the task of the story-teller to talk his hearers to sleep. The best story-tellers boast of never having told any story to the end.

The legends are known to all; it is the grandmother's business to teach them to her grandchildren.

This is the first time that the legends of the Polar Eskimos have been put on record, and my principle, during my task, has been never to repeat any story until I myself had learnt it and told it. In this way I made the whole manner of the story-telling my own, and I have endeavoured, as far as possible, to give literal translations. (Rasmussen 1908: 159)

Opinions vary about the authenticity of the tales that Knud Rasmussen collected among the Eskimos in this fashion, but my point here is to stress his analogical method as a way of entry into the thought of others, and the fact that narration is also a form of dwelling (Ingold 2000). He was always directly engaged with the material, moving, gesturing, dancing, reciting, and making his own poetic interventions along the road. When the Eskimos were pleased with his performance, so was he.

His practice parted company from the folklore collector's method, as known from Europe, because it was only possible even to begin 'collecting' if one shared the life of the people and moved along with them (e.g. Rasmussen 1929: 11). This he practised also among the Polar Eskimos, when he was less conscious about his own role, and he described again and again how friendship and intimacy were instrumental to the access to knowledge. Knud Rasmussen collected, charted and represented-and added new knowledge of the Eskimos and their internal relations. While always writing with the European audience in mind, Knud Rasmussen never forgets the feeling of Eskimo life; his work bears on a recently articulated anthropological argument that knowledge of others is often a matter of sociality (Jackson 1995: 119). It has been noted how Knud Rasmussen was downright 'in love with Eskimo imagination and intelligence' (Sonne 1988). There is a sense of complete surrender to the friends and freedoms of the North; in this icy world, there was no external position from where you could simply look at the natives. Intimacy, to varying degrees, was part and parcel of Arctic exploration (Pálsson 2004).

For Radcliffe-Brown, method was a different matter; it was not a surrender to anything but scientific meticulousness. One of his earliest observations on method surfaces in a rejoinder to Father Schmidt in 1910. The latter had criticised a paper on 
certain features of Andamanese religion made by a newly returned Brown (1909), as he was still called then. Father Schmidt had implied that earlier observations by $\mathrm{Mr}$ Man and Mr Portman were more reliable, and although Radcliffe-Brown would have preferred not to answer back and finds it extremely unpleasant, he feels compelled to address the issue of method raised by Father Schmidt, whose work is an example of the 'worst methods', because he is looking only for support for a preformed theory, while Radcliffe-Brown himself operates with strict methods of observation and interpretation, and is adamant that: 'The first rule of scientific method is to approach every new problem with a mind free from preconceived opinions'-which Father Schmidt corrupts completely (Brown 1910: 33). He then points out the steps by which he arrived at conclusion, with which Father Schmidt disagrees. The conclusion is stark:

I have replied at length upon Father Schmidt's attack upon me, because it brings forward the fundamental disagreement that exists between those of us who are endeavouring, by an insistence on strict methods, both of observation and interpretation, to make ethnology a science fit to rank with other sciences, and those writers who, by following such unjustifiable methods as those to be found in Father Schmidt's note, hinder the progress of our science. It is probably too late to hope that Father Schmidt will change his methods, but I have availed myself of this opportunity of showing what those methods are. (Brown 1910: 37)

We get an early glimpse here of an anthropologist with a mission to establish a rigorous anthropological science in the face of dominant schools, by way of a strictly inductive method. In the words of Adam Kuper, offering a general depiction in 1977: 'He was a pioneer, even a prophet, and although unusually successful he exhibited many of the characteristic traits of rigidity and extreme sensitivity to criticism' (Kuper 1977b: 3). This scientific pioneering came with a loss in the domain of fieldwork, I would argue, and I substantiate this below. An interesting clue is provided by RadcliffeBrown himself in his defence of the comparative method in social anthropology; looking back upon his predecessors in the field, he relates how Haddon had urged the need for intensive field studies by competent observers, and he continues:

The development of field studies has led to a relative neglect of studies making use of the comparative method. This is both understandable and excusable, but it does have some regrettable effects. The student is told that he must consider any feature of social life in its context, in its relation to the other features of the particular social system in which it is found. But he is often not taught to look at it in the wider context of human societies in general. (Radcliffe-Brown 1951; in Kuper 1977a: 54)

When Radcliffe-Brown set out for the Andaman Islands, his view of anthropology had not yet been fully formed. Nor indeed were his own observations of a nature that allowed for a structural study. His teacher at Cambridge, W.H.R. Rivers, who had 
been part of Haddon's Torres Straits Expedition, had developed the genealogical method, which had enabled him to visualise kinship, and therefore also to break away from earlier modes of representation. Anna Grimshaw has made a parallel between this feat and Paul Klee's observation on art: 'Art does not render the visible; rather it makes visible' (Grimshaw 2001: 37). Such also was the vision of the ethnographic artwork inherent in the genealogical method, and this was exactly what RadcliffeBrown did not deliver. First, literally, he did not master the genealogical method, as he confessed in his book: 'I collected a number of genealogies from the natives, but unfortunately my own inexperience in the use of the genealogical method, and my consequent inability to surmount the difficulties with which I met, made this branch of my investigation a failure' (Radcliffe-Brown 1922: $72 \mathrm{n}$.).

Radcliffe-Brown's fieldwork had not been easy for him; his main work had been done from the vantage point of the penal colony, at a time when the population had fallen below 1,300, and he had a hard time even talking to people without knowing the language. He therefore settled on interviewing English-speaking informants around Port Blair, and declared that 'what is really of interest to the ethnologist is the social organization of these tribes as it existed before the European occupation of the islands' (1922: 22). The result is make-believe - a collapse of past and present, and of colonial and native points of view. Significantly, when he later went to Australia and quickly fell out with the Aborigines, he moved camp to Bernier island - 'the site of a lock-up hospital for Aborigines infected with venereal disease. The occupants had mostly been kidnapped and forcibly been removed there, but the party spent several months pursuing with these unfortunate informants their researches into the traditional Aboriginal marriage systems' (Kuper 1975: 60).

The search for a system intensified, and I believe that one reason why RadcliffeBrown's book on the Andaman Islands was not published until 1922, was that he had no way of identifying such a system. He saw the natives only out of the corner of his eye, and became increasingly focused on abstract problems. If, as suggested by Grimshaw, Malinowski's style of writing was 'painterly', 'drawing on the techniques of the artist to create a rich, textured picture of native society' (Grimshaw 2001: 55), for Radcliffe-Brown, the gaze had become a disembodied instrument of observation (ibid.: 67). Radcliffe-Brown's increasingly normative position, and his concern with systems and rules, was to limit his writing (he had published surprisingly little), because there was no limitless resource for revelation in actual conversations with people. His new, rationalistic, bent—after his first fieldwork, which after all did result in a monograph, can be seen for instance in his own judgement of Andamanese myths and traditions. These did not really add up to a system. Here is his discussion of narrative variation: 
The Andamanese have a number of stories which are told to the younger people by their elders and relate to the doings of their ancestors in a time long ago. Some of these stories are recorded in this chapter. A difficulty in the way of giving any clear and readable account of them is the fact that there are many slightly different versions of one and the same legend. To some extent the variations are local, each tribe, and even each portion of a tribe having its own set of legendary stories. Besides these local variations there are also individual variations. Two men of the same tribe may relate what is substantially the same story, yet each chooses his own words and gestures, and to some extent may even arrange the incidents differently. (Radcliffe-Brown 1922: 186)

Bearing in mind how Knud Rasmussen wrote of the delightful originality of Eskimo story-telling, we note how Radcliffe-Brown finds only tiresome variation. Even so, he insisted that 'underlying the legends of any tribe there are a certain number of beliefs or representations with which every native is familiar' (ibid.: 187). This is actually somewhat out of tune with a later statement about the lack of systematic coherence between different ritual and ceremonial customs, leading Radcliffe-Brown to reject the use of the term 'religion' for the Andamanese beliefs (and again, implicitly, taking the opposite stance to the likes of Father Schmidt).

If a 'system' exists, it is only located in a working hypothesis, which actually frames the analysis of the beliefs: 'A society depends for its existence on the presence in the minds of its members of a certain system of sentiments by which the conduct of the individual is regulated in conformity with the needs of society' (1922: 233-4). The following passage is testimony to both his dream of a system, and the need to look back in time to find it.

At the present time it is only possible to recover a small part of the many different legends with their variants. The introduction of many new interests into the lives of the natives, through the European settlement and the many changes it has produced, has caused the ancient legends to be neglected...

One feature of the legends that must be pointed out is their unsystematic nature. The same informant may give, on different occasions, two entirely different versions of such a thing as the origin of fire, or the beginning of the human race. The Andamanese, to all appearance, regard each little story as independent, and do not consciously compare one with another. They thus seem to be entirely unconscious of what are obvious contradictions to the student of legends. (Radcliffe-Brown 1922: 188)

It annoys him that people cannot see the obvious contradictions-obvious to him as the outside onlooker. There is no participation in the delight of storytelling, just as there was never much true fieldwork in the new sense of being there, emerging at the time out of the work of the Torres Strait expedition. He was never really there, it seems, and that is a major reason for certain constant elements of his style. 'His work 
has a glacial clarity, and his concern was always with the formal situation, the rules and the rituals' (Kuper 1975: 56). In rather remarkable disregard for the colonial breakdown of the native population, and disregarding the sad and scattered population, which he only knew from 'outside', so to speak, he sought to establish some system, in which readers could have faith:

In an enquiry such as this, we are studying, I take it, not isolated facts, but a 'culture', understanding by that word the whole mass of institutions, customs and beliefs of a given people. For a culture to exist at all, and to continue to exist, it must conform to certain conditions. It must provide a mode of subsistence adequate to the environment and the existing density of the population; it must provide for the continuance of the society by the proper care of children; it must provide means for maintaining the cohesion of the society. All these things involve the regulation of individual conduct in certain definite ways; they involve, that is, a certain system of moral customs. (Radcliffe-Brown 1922: 400-1)

Radcliffe-Brown had to use all his skills to convince us that there was such an Andamanese culture; methodologically, he placed himself squarely outside it. He had no part in their system of moral customs. It is significant, I believe, that in his later career, references to the work among the Andaman Islanders are very sparse, as is indeed his oeuvre more generally (see, e.g. Radcliffe-Brown 1952, where the Andaman Islanders are all but absent). In his monograph, which he held back for 15 years, he seems not to be convinced about his own version of their world. The 'parts' do not really add up to a whole. He mentions distinct 'tribes' on the islands, but does not really believe in their separate existence (and he does not go inland to see for himself); remaining on the outskirts, he also remained a spectator. And he honestly notes his difficulties in doing his work, for instance with regard to kinship, where he had to make do with some rather basic description of family relations. He then adds a note:

It would not be safe, however, to base any arguments of importance to sociology on the above description of the Andamanese system of relationship alone. Although I tried to learn all I could on the subject, it is quite certain that I did not learn all that was to be learnt, and it is possible that further enquiry might have shown that I was mistaken in some of my observations. The difficulty of being really sure on these matters is due (1) to the fact that breaking-up of the old local organisation has produced many changes in their customs, and (2) to the difficulty of questioning the natives on matters connected with relationships when they have no words in this language to denote any but the simplest relationships. (Radcliffe-Brown 1922: $82 \mathrm{n}$.)

The issue of language is important; in contrast to Knud Rasmussen, Radcliffe-Brown never learnt it, but he was also hampered by his ingrained sense of the necessity of finding some system that held everything together. Rasmussen, along with Boas, had a completely different view of culture, as a loosely integrated pattern of language, 
stories, skills, and artefacts. It was a culture without boundaries, and with which one had to engage more directly in order to make the connections. Connections do not add up to cohesion; culture is on the level of events and actions, and is in principle unbounded. The methodological strategies placed and also moved Knud Rasmussen along with the people he wanted to know, as we heard above. This difference, of course, had a lot to do with different European traditions, but also, I would ague, with the distinct landscapes and histories that adhered to the people and their explorers. Rasmussen had not read Boas before his fieldwork among the Polar Eskimos, but in order to study the tiny population (c.250 people) in the vast region, he had to travel with and dwell among the people - literally, because there was no way to keep warm outside the tiny tents, igloos, or turf-and-stone huts. This fate was accepted with much delight.

While Radcliffe-Brown turned his back on people and principally interviewed them under conditions of weakness and captivity, Rasmussen nurtured long-lived friendships with the Polar Eskimos, to whom he returned again and again-and among whom he had established the trading station at Thule. Two of them, Qâvigarssuaq and Arnarúlunguak, accompanied him on the long sledge-journey across Arctic North America, 1921-4, the former mainly as hunter, the latter as householder and mender of the skin clothes. They made his home in the North, and were with him when he returned to Denmark, by way of New York, and also when he received his honorary doctorate at the University of Copenhagen. Today, one of my finest acquaintances in the Thule area is Qâvigarssuaq's granddaughter, and much to my delight she told me that in their eyes it was he who was the great sledge-driver, not Knud Rasmussen. It was the grandfather's tales from America and Copenhagen that survived in the far North, even if it was Knud Rasmussen's work that was published (albeit with emphatic acknowledgement of his debt to his named Polar Eskimo friends).

\section{NARRATIVE GESTURES: EMERGING ETHNOGRAPHIC SUBJECTS}

By holding the two ethnographers up as mirrors to one another, we may learn something new about both in their distinction from each other. More importantly, perhaps, we get a fresh view of the early years of anthropological fieldwork taking shape in vastly different landscapes and being performed by different persons each with their own biographical trajectories. I have not dealt explicitly with issues of personality, rather wanting to stress the importance of the different historical spaces into which the ethnographers entered - and to which their work contributed.

Given the particular colonial history of the Andaman Islands, and the not unrelated fact of Radcliffe-Brown's external perspective and his objectifying gaze, it is 
no surprise that the Andaman Islanders were portrayed as types, belonging to a particular Negrito race of long-lasting and consistent ill repute. Conversely, casting himself as the discoverer of the new people in High Arctic Greenland, Knud Rasmussen has no qualms in incorporating the Polar Eskimos into his circle of friends, who despite their bear skin clothes were really very much like his childhood playmates further south in what was then called Danish Greenland; this also pertained to their language. As friends, the Polar Eskimos invariably featured as named individuals in his work. Of course, there were named individuals in the Andaman Islands and also in the colonial records, but they disappeared out of view in most other writings - certainly in Radcliffe-Brown's (see also Anderson 2012). For him, the Andaman Islanders remained anonymous exemplars of a particular race who potentially gave insight into the general laws of society.

In the Arctic, Knud Rasmussen's (later) search for and documentation of linguistic and cultural unity within all the Eskimo groups made individuals stand out. In the ethnographic works from North America resulting from his 1921-4 expedition, he named some 1,200 native informants in northern Canada, where the population at the time is estimated to have been $c .10,000$ - and he almost literally met them all and incorporated everybody in his background description. This makes a remarkable difference between the ethnographic subjects that emerge in the two men's writings - types or persons - and it is in many ways a function of the ethnographers' relative position within or without local society. If one shares the sleeping platform with families and friends, these cannot remain anonymous for long. The paradox embedded here is that through such closeness and recognition of individual distinction, the shared humanity is foregrounded in Rasmussen's work.

The narrative styles of our two protagonists reflect the ways in which they approached and moved about in the Tropical and Arctic landscapes, respectively. Radcliffe-Brown remained on the outskirts of Andaman society, wary of entering and mostly interviewing people who already lived in the colony. There is no shame in this, but it did not match his professed wish to describe the original Andaman culture, which largely eluded him by being inaccessible in both time and space. Knud Rasmussen, on the other hand, involved himself completely with the Eskimo, moved along with them, shared their dwellings and their stories, and became engaged in analogue mapping practices. The Eskimos were always renowned for their 'cartographic' skills, embedded in toponyms and other narrative gestures (Hastrup 2013b).

We may get more a comprehensive view of the different narrative genres employed by our protagonists if we look towards Bakhtin's analysis of time and chronotope in the novel (1981). In the literary chronotope, 'spatial and temporal indicators are fused into one carefully thought out, concrete whole. Time, as it were, takes on flesh, becomes 
artistically visible; likewise, space becomes charged and responsive to the movements of time, plot, and history' (Bakhtin 1981: 84). This resonates well with what we might call lived chronotopes or those historical topographies with which people live. Chronotopes are 'the organizing centres for the fundamental narrative events of the novel. The chronotope is the place where the knots of narrative are tied and untied' (ibid.: 250). When dealing with ethnographic writing, the relative position of the writer vis-à-vis the ethnographic subjects is inscribed into the narrative form.

This is why we may, at least tentatively, use the notion of the chronotope to qualify the distinct ethnographic genres of our main characters. Bakthin suggests that there are two dominant literary chronotopes, one of the encounter and one of the threshold, which I would suggest as significant 'knots' in the cited Arctic and Andamanese ethnographies respectively. In the chronotope of the encounter, the temporal element predominates and the encounter itself is intensely loaded with emotions and values (Bakhtin 1981: 243). The encounter opens up for new histories, because different fates collide; the fates of people who are normally separated by social and spatial distance interweave, and social distances collapse. This aptly captures Rasmussen's ethnographic mode of travelling along, of meeting people en route, and taking such delight in every new encounter that this carries his narrative forward and deepens his understanding.

In the case of Radcliffe-Brown, we are nearer to the chronotope of the threshold. Bakhtin says about this particular knot that,

its most fundamental instance is as the chronotope of crisis and break in life. The word 'threshold' itself already has a metaphorical meaning in everyday usage (together with its literal meaning), and is connected with the breaking point of a life, the moment of crisis, the decision that changes a life (or the indecisiveness that fails to change a life, the fear to step over the threshold)...

In this chronotope, time is essentially instantaneous; it is as if it has no duration and falls out of the normal course of biographical time. (Bakhtin 1981: 248)

As I read Radcliffe-Brown's ethnography of the Andaman Islanders, he stands indecisively on the threshold and dares not take the plunge into the alternative space, for fear of losing his foothold. At the same time, and even as he relates historical facts, the narrative time gives no sense of duration, nor a sense of history-except a loose indication of then and now-let alone of the author's own biographical time. Radcliffe-Brown remained outside the world he studied, partly because in some sense the inlands resisted penetration, partly because he sought to maintain an objective stance. This earned him a lot of success as a general thinker of rules, models, and relations - to the point where he was even called a prophet of his time, as we heard. The threshold on which he stood was deeply marked by an already troubled colonial relation, which it seemed impossible to overstep. 
Knud Rasmussen never became famous in anthropology in general, although his extensive documentation of pan-Eskimo life remains a rich source in early Arctic ethnography. The narrative style echoes the movements he made in a vast and largely uncharted territory, where he joined in with others-whether camping, hunting, dancing, or telling stories. And wherever he went, also on the three year long fifth Thule expedition he was in the company of some friends from Thule. They made up his moving home, all while he discovered the Eskimo world along with them. Even when he established the trade station he was still catering for their needs (they agreed at the time); while riding on the last, but still powerful wave of Polar exploration, his ethnography derived from taking part in Eskimo life and narrative (Hastrup 2010b). Successive encounters and the collision of fates opened up for new stories that entwined the ethnographer and his subjects in one and the same historical space, where even colonial relations could be established as analogue, and where biography and ethnography fused.

While it remains difficult to really compare two very early ethnographers and their work, being so very different from each other, I believe that we may find in their work some of the reason for the tenacity of tropes in ethnographic writing. While Arctic explorers longed to conquer the landscape and could only do so by emulating the locals, and by letting themselves be absorbed and affected to their bodily core, the travellers on the Indian seas never dreamt of becoming at one with either landscapes or peoples. To overstep the threshold was to lose oneself, and to face a crisis of language and being. By contrast, in the Arctic encounter, the parties were equally engaged in conversation, taking place across subjective understandings and disbanding social distances.

What we have to acknowledge in ethnographic writing as well as in literature, is that 'the word in language is half someone else's' (Bakhtin 1981: 293). When Bakhtin further qualifies this, we get nearer to a closure of my implicit argument. He says: 'Each word tastes of the context and contexts in which it has lived its socially charged life; all words and forms are populated by intentions. Contextual overtones (generic, tendentious, individualistic) are inevitable in the word' (Bakhtin 1981: 293). This is also the case for the words 'Andaman Islanders' and 'Polar Eskimos', bearing the marks of early ethnographies and the distinct relations between the ethnographers and the ethnographic subjects unfolding in particular historical spaces.

This finally makes me revisit the 'ethnographic moment', defined by Marilyn Strathern as a moment of knowledge or insight, which 'denotes a relation between immersement and movement' (Strathern 1999: 6). Ethnographers work in the field with writing in mind, and while immersement may yield the unlooked for, I would argue that it is already imbued with complex spatial and narrative histories. The moment is as extensive as it is elusive. The holistic enterprise, hailed by Radcliffe- 
Brown, was a sincere attempt at making anthropology scientific, but in the process I would venture that he may have failed in terms of ethnographic sensibility. For Knud Rasmussen the opposite seemed to have been the case.

In spite of all our sophisticated awareness about the long spatial histories that qualify our fields, we cannot really get beyond them; nor can we get beyond our own research interest. What we must continue to nurture is an ethnographic practice of working with people in the field, because this is what will keep anthropology alive and ready to address new large questions as they arise from the encounter.

\section{Acknowledgements}

I want to thank the British Academy for the honour of being invited to give the Radcliffe-Brown Lecture 2012, and the two audiences in St Andrews and London respectively for their attention and stimulating discussion, enabling me to make the final clarifications in the enlarged written version. The anonymous reviewer and the Editor of the Journal of the British Academy are also thanked for their productive comments.

\section{REFERENCES}

Anderson, C. (2007), The Indian Uprising of 1857-8. Prisons, prisoners and rebellion (London: Anthem Press).

Anderson, C. (2011), 'Colonization, kidnap and confinement in the Andamans penal colony, 1771-1864', Journal of Historical Geography, 37: 68-81. http://dx.doi.org/10.1016/j.jhg.2010.07.001

Anderson, C. (2012), Subaltern Lives. Biographies of colonialism in the Indian Ocean world, 1790-1920 (Cambridge: Cambridge University Press). http://dx.doi.org/10.1017/CBO9781139057554

Astrup, E. (1895), Blandt Nordpolens Naboer (Kristiania: Aschehough \& Co.s Forlag).

Astrup, E. (1898), With Peary near the Pole (London: Arthur Pearson).

Bakhtin, M.M. (1981), The Dialogic Imagination (Austin: University of Austin Press). PMid:7279199

Boas, F. (1964 [1888]), The Central Eskimo (Lincoln/London: The University of Nebraska Press).

Brown, A.R. (1909), 'Religion of the Andaman Islanders', Folk-Lore, 20 (3): 257-71. http://dx.doi.org/10.1080/0015587X.1909.9719883

Brown, A.R. (1910), 'Puluga: A Reply to Father Schmidt', Man, 10: 33-7. http://dx.doi.org/10.2307/2788829

Burke, E. (1998 [1757]), Philosophical Enquiry into the Orgin of our Ideas of the Sublime and Beautiful (World's Classics; Oxford: Oxford University Press).

Crawfurd, J. (1865), 'On Sir Charles Lyell's “Antiquity of Man”, and on Professor Huxley's “Evidence as to Man's Place in Nature"', Transactions of the Ethnological Society of London, 3: 58-70. http://dx.doi.org/10.2307/3014155

Fabian, J. (2000), Out of Our Minds. Reason and madness in the exploration of Central Africa (Berkeley: University of California Press). http://dx.doi.org/10.1525/california/9780520221222.001.0001

Fardon, R. (1990), Localizing Strategies: Regional traditions of ethnographic writing (Edinburgh and Washington: Scottish Academic Press and Smithsonian Institution Press). PMid:2208978

Grimshaw, A. (2001), The Ethnographer's Eye. Ways of seeing in modern anthropology (Cambridge: Cambridge University Press). http://dx.doi.org/10.1017/CBO9780511817670 
Hastrup, K. (2006), 'Knud Rasmussen (1879-1933). The Anthropologist as Explorer, Hunter and Narrator', Folk. The Journal of the Danish Ethnographic Society, 46/47: 159-80.

Hastrup, K. (2007), 'Ultima Thule. Anthropology and the Call of the Unknown', Journal of the Royal Anthropological Institute, 13: 789-804. http://dx.doi.org/10.1111/j.1467-9655.2007.00457.x

Hastrup, K. (2009), 'Arctic Hunters. Climate Variability and Social Flexibility', in K. Hastrup (ed.), The Question of Resilience. Social responses to climate change (Copenhagen: The Royal Danish Academy of Sciences and Letters), 245-70.

Hastrup, K. (2010a), 'Emotional Topographies: The Sense of Place in the North', in J. Davies and D. Spencer (eds), Emotions in the Field (Palo Alto: Stanford University Press), 191-212.

Hastrup, K. (2010b), Vinterens hjerte. Knud Rasmussen og hans tid (Copenhagen: Gads Forlag). PMCid:PMC2804221

Hastrup, K. (2013a), 'The Ice as Argument. Topographical Mementos in the High Arctic', Cambridge Anthropology, 31 (1): 52-68. http://dx.doi.org/10.3167/ca.2013.310105

Hastrup, K. (2013b), 'Anticipation on Thin Ice. Diagrammatic Reasoning in the High Arctic', in K. Hastrup and M. Skrydstrup (eds), The Social Life of Climate Change Models. Anticipating Nature (London and New York: Routledge), 77-99.

Hastrup, K. (3013c), 'Of Maps and Men. Making Places and Peoples in the Arctic', in K. Hastrup (ed.), Anthropology and Nature (London and New York: Routledge), 211-32.

Huntford, R. (1997), Nansen. The Explorer as Hero (London: Duckworth).

Ingold, T. (2000), The Perception of the Environment. Essays in livelihood, dwelling, and skill (London: Routledge). http://dx.doi.org/10.4324/9780203466025

Ingold, T. (2008), 'Anthropology is Not Ethnography', Radcliffe-Brown Lecture in Social Anthropology 2007. Proceedings of the British Academy, 154: 69-92.

Jackson, M. (1995), At Home in the World (Durham and London: Duke University Press).

Kuper, A. (1975), Anthropologists and Anthropology. The British School 1922-72 (London: Penguin Books). PMid:1180307

Kuper, A. (ed.) (1977a), The Social Anthropology of Radcliffe-Brown (London: Routledge and Kegan Paul).

Kuper, A. (1977b). 'Preface', The Social Anthropology of Radcliffe-Brown (London: Routledge and Kegan Paul), 1-7.

Lefebvre, L. (1991), The Production of Space (trans. D. Nicholson-Smith) (Oxford: Blackwell).

Malinowski, B. (1922), Argonauts of the Western Pacific (London: Routledge and Kegan Paul).

Man, E.H. (1932 [1885]), On the Aboriginal Inhabitants of the Andaman Islands (London: The Royal Anthropological Institute). (Reprinted from the Journal of the Anthropological Institute, 1885).

Massey, D. (2005), For Space (London: Sage).

Mauss, M. (1979 [1906]), Seasonal Variations of the Eskimo. A study in social morphology (with H. Beuchat; trans. J.J. Fox) (London: Routledge and Kegan Paul).

Müller-Wille, L. (ed.) (1998), Franz Boas among the Inuit of Baffin Island, 1883-84: Journals and Letters (ed. and introd. L. Müller-Wille; trans.W. Barr) (Toronto: University of Toronto Press).

Pálsson, G. (2004), 'Race and the Intimate in Arctic Exploration', Ethnos, 69: 363-86. http://dx.doi.org/10.1080/0014184042000260053

Pandya, V. (2007), 'Time to move: winds and the political economy of space in Andamanese culture', Journal of the Royal Anthropological Institute: Special Issue, S91-S104. http://dx.doi.org/10.1111/j.1467-9655.2007.00404.x

Pandya, V. (2009), In the Forest. Visual and material worlds of Andamanese history (1858-2006) (Lanham, Boulder, New York, Toronto and Plymouth, UK: University Press of America).

Peary, R. (1898), Northward over 'The Great Ice'. A Narrative of Life and Work along the Shores and upon the Interior Ice-Cap of Northern Greenland in the Years 1886 and 1891-1897. With a description of 
the Little Tribe of Smith-Sound Eskimos, the most northerly Human Beings in the World, and an Account of the Discovery and Bringing Home of the 'Saviksue,' or the Great Cape-York Meteorites (London: Methuen \& Co).

Pratt, M.L. (1992), Imperial Eyes. Travel writing and transculturation (London: Routledge).

Radcliffe-Brown, A.R. (1922), The Andaman Islanders (Cambridge: Cambridge University Press).

Radcliffe-Brown, A.R. (1977 [1951]), 'The comparative method in social anthropology', in A. Kuper (ed.), The Social Anthropology of Radcliffe-Brown (London: Routledge), 53-69.

Radcliffe-Brown, A.R. (1952), Structure and Function in Primitive Society (London: Cohen and West; New York (1965): Free Press).

Radcliffe-Brown, A.R. (1958), Method in Social Anthropology. The major writings on method by the founder of the scientific study of social anthropology, ed. M.N. Srinivas (Chicago: University of Chicago Press).

Rasmussen, K. (1905), Nye Mennesker (København og Kristiania: Gyldendalske Boghandel/Nordisk Forlag).

Rasmussen, K. (1906), Under Nordenvindens Svøbe (København og Kristiania: Nyt Nordisk Forlag).

Rasmussen, K. (1908), The People of the Polar North (compiled from the Danish originals and ed. G. Herring) (London: Kegan Paul, Trench, Trübner \& Co.).

Rasmussen, K. (1921), 'Thule Distrikt', in G.C. Amdrup, L. Bobé, A.S. Jensen, H.P: Steensby (eds), Grønland $i$ Tohundredåret for Hans Egedes Landing, vol. I (København: C.A. Reitzels Forlag. Meddelelser om Grønland), vol. 60: 517-67.

Rasmussen, K. (1925-6), Fra Grønland til Stillehavet. Rejser og Mennesker fra 5. Thule-Ekspedition, 1921-4 (København: Gyldendalske Boghandel/Nyt Nordisk Forlag) (vols I and II).

Rasmussen, K. (1929), Intellectual Culture of the Iglulik Eskimos (Report of the Fifth Thule Expedition 1921-4) (København: Gyldendalske Boghandel). PMid:19969849 PMCid:PMC2007246

Rasmussen, K. (1932), Den store sladerejse (København: Gyldendal).

Riffenburgh, B. (1993), The Myth of the Polar Explorer. The Press, sensationalism, and geographical discovery (London and New York: Belhaven Press and Scott Polar Research Institute, University of Cambridge). PMid:8321524

Ross, J. (1819), Voyage of Discovery, made under the orders of Admiralty, in his Majesty's ships Isabelle and Alexander, for the Purpose of Exploring Baffin's Bay, and inquiring into the probability of a NorthWest Passage (London: John Murray).

Sonne, B. (1988), 'In Love with Eskimo Imagination and Intelligence', Inuit Studies, 12: 24-41.

Strathern, M. (1999), 'The Ethnographic Effect', in M. Strathern (ed.), Property, Substance and Effect. Anthropological essays on persons and things (London and New Brunswick, NJ: The Athlone Press), 1-26.

Taussig, M. (1993), Mimesis and Alterity. A particular history of the senses (New York and London: Routledge). PMCid:PMC46364

Turnbull, D. (2003), Masons, Tricksters and Cartographers. Comparative Studies in the Sociology of Scientific and Indigenous Knowledge (London and New York: Routledge).

Tylor, E.B. (1863), 'Wild Men and Beast-Children', Anthropological Review, 1: 21-32. http://dx.doi.org/10.2307/3024982

Vaidik, Aparna (2010), Imperial Andamans. Colonial encounters and island history (Basingstoke and New York: Palgrave Macmillan). http://dx.doi.org/10.1057/9780230274884

The author: Kirsten Hastrup is Professor of Anthropology at the University of Copenhagen. She has done substantial research on Icelandic history and society, and 
on early polar expeditions and the emergence of Arctic anthropology. Over the past six years she has done fieldwork in Northwest Greenland, where the small hunting community is greatly affected by climate change. In addition to these more specialised fields, she has published critical explorations of the foundations of anthropology. She was elected a Corresponding Fellow of the British Academy in 2011. Contact: Kirsten.Hastrup@anthro.ku.dk

This article is licensed under a

Creative Commons Attribution-NonCommercial-NoDerivs 3.0 Unported License.

Journal of the British Academy (ISSN 2052-7217) is published by

The British Academy - the national academy for the humanities and social sciences.

10-11 Carlton House Terrace, London, SW1Y 5AH

www.britac.ac.uk 